\title{
Theories of knowledge and the experience of being: Jainism's ontology of kinship
}

Anne Vallely

Correspondence:

avallely@uottawa.ca

Department of Classics and

Religious Studies, University of

Ottawa, Ottawa, Canada

\section{Springer}

\begin{abstract}
This paper explores Jain epistemology and hermeneutics as derivative of an ontology of kinship or of 'being with'. The distinctively Jain 'way of being' stems from an experiential reality of inhabiting a world that is concretely and patently inhabited by others. Methodologically, the paper draws on Umāswāti's Tattvārtha Sütra, as well as on ethnographic work on Jainism. The paper demonstrates that embodied perceptions of an animate cosmos are far more fundamental than any of its individual metaphysical claims for understanding the Jain relation to the world. It is argued that these embodied perceptions constitute the generative ground from which Jain philosophical and ethical reflections emerge. Jainism's insistence on the concrete experience of being sentiently with others informs its ethical frameworks and epistemological insights, and serves as the foundational source for understanding life's existential purpose. This paper concludes by arguing that the primary impetus for Jainism's celebrated focus on nonviolence, as well as its extraordinary attention to the non-human, is not epistemological, but experiential.
\end{abstract}

\section{Background}

Jain conceptual scaffolding reaches bewildering heights and plumbs unfathomable depths, with concepts building upon concepts, filling the intricacies of the lokäpuruşa in a manner oblivious to the heart's desire for simplicity. Reality is presented as a perfectly logical and minutely detailed system, constituted by a bewildering array of sentient beings, some invisible, all catalogued according to senses, karma, time cycles and geographical space. Everything is given in superlatives: measurements are immense, distances are indecipherable, and numbers are beyond ordinary comprehension. We learn, for instance, that the continent of Bharata is 526 6/19ths yojanas wide, and that the inhabitants of another continentthe Videha-can live up to one pürvakoți, which is $8,400,000$ (to the power of 2 ) $\times 10$ (to the power of 7) time units. This is the stuff of Jain philosophy, of the great 2nd century Ācārya Umāsvāti whose treatise, the Tattvārtha Sütra has come to be a classic, canonical text of Jain philosophical thought. But what are we to make of this finely detailed, minutely constructed epistemological labyrinth? What does it tell us about Jain ways-of-knowing (epistemology) and being in the world? Not much, I suggest. Outside of the few ācāryas for whom systematizing the workings of the cosmos is a form of sädhana and thereby a karma-burning (nirjarā) activity, for most Jains, the impact of these bewildering abstractions can only be a deep sense of wonder-or perhaps dread. Mircea Eliade-writing on Hinduism-has suggested that such cosmological elaborations function to induce a desire

(c) 2013 Vallely; licensee Springer. This is an Open Access article distributed under the terms of the Creative Commons Attribution License (http://creativecommons.org/licenses/by/2.0), which permits unrestricted use, distribution, and reproduction in any medium, provided the original work is properly cited. 
for mokşa (Eliade 1987). At a minimum, they communicate to Jains a message that the world is neither random nor whimsical, but purposeful. But, while the powers of cosmic rationalization and systematization may be dazzling, I want to argue here that the genius of Jainism lies elsewhere. It is derived from the soil under our feet, the scents and sounds that engulf us, and the movement of our bodies through animate space.

In this paper I argue that Jainism has always recognized that epistemology is the handmaiden to experience. Though the Jain philosophical tradition is an ancient and esteemed one, with sophisticated and complex theories on the nature of reality and knowledge, the embodied and experiential way of relating to the world carries greater force. The Jain path is renowned for its physical rigor and concreteness: the naked Digambara muni bears witness to the fact that, for Jainism, truth is not achievable through intention alone. For all Jains, ahimssā is far more than a state of mind or orientation. Its effectiveness lies is in the degree to which it is fully inhabited, concretely actualized in the way one walks, talks, sits, eats etc. And the Jain predilection for observing and cataloguing the natural world likewise stems from this focused attention on embodied existence. The conceptual and abstract can never take on a life of its own, independent of its embodied, sensory beginnings. The sensing, experiencing body is at the center of Jain ways of being, and of Jain ways of knowing. This is the implicit message in Umāsvāti's canonical Tattvārtha Sütra, and Nathmal Tatia, its esteemed translator, summarizes the sütra's message by saying that in Jainism "Insistence of life" is a superior moral value to "insistence of truth" because the nature of truth varies from thinker to thinker but life is an invariant constant that is dear to all" (Umāsvāti 1994: xxi).

Emphasizing life over truth is to valorize embodied existence over and above the reflections on it. This calculated focus on lived existence itself-up close and on the groundhas led to an awareness in Jainism that life, most fundamentally, expresses itself relationally -with other sentient beings and with a meaningful world. Epistemologically, this had led to an awareness that perceptual engagement with other sensory beings is the foundation of all knowledge. Ontologically, it treats as given the existence of an independent domain of meaning that is received (not constructed). In terms of contemporary relevancy, it is hard to think of a set of notions with greater import. The dominant modern way conceiving of the human being represents a radical departure and rejection of these dimensions of life: we alone are meaning-makers in an otherwise mute world; cognitive beings who are condemned to imaginatively create the world in order to engage with it. Concerned only with the cognitive relationship to the world, the modern view disregards (or worse, flatly denies) the possibility of meaning inherent in the world itself as well as all knowledge that is immanent in experience. Jainism circumvents this tendency due to its embodied epistemology (that is, an epistemology that never strays far from ontology), and therefore is worth our close consideration. I want here to explore the two implications of the Jain way of being/knowing in greater detail.

\section{Animate cosmos \& the non-human other}

Non human sentient life is at the very center of the Jain religious imagination - its cosmology, philosophical musings, ethics, and its notions of what it means to be a fully realized human being. For those new to the study of the Jain dharma, the tremendous focus on the non-human is often one of its most striking features. Ethical attention 
extends far beyond human-to-human engagements, and often seems (to the uninitiated) excessively focused on beings with little or no subjectivity at all (e.g., water- and soil-bodied beings, miniscule insects). Fascinatingly, despite its bio-centricity and its insistence on the inviolability of all life, Jainism unequivocally considers human beings as distinct from and superior to all other life forms, and in this way differs from much contemporary eco-philosophical discourse. Despite transgressing the bio-centric ethos so celebrated within most of contemporary environmental thought, as well insisting on the existence of an ontological gap between humans and nonhumans, Jainism recognizes the world in its entirety as purposeful, intelligent, and responsive. It is this fundamental awareness that has given rise to Jainism's "grounded" epistemology, and which has informed the tradition's celebrated tradition of nonviolence of the past nearly 3000 years. To put this another way, recognizing the world as animate and intentional, and capable of suffering, may be far more crucial a recognition than where one can be plotted along the anthropocentric-bio-centric ideological spectrum. Elsewhere, in a paper that deals more fully with the issue of the nonhuman, I have argued:

The distinctively Jain way of being stems from the experiential reality of inhabiting a world that is concretely and patently inhabited by others: It takes for granted the experience of life as always and unavoidably in a state of being with others. The animate and intelligent life that encompasses us, that perpetually bombards us, and leaves its innumerable impressions on us every moment of every day, is, for Jains, taken as given (Vallely 2014).

In another area of divergence from mainstream environmental thought, Jainism does not consider human plenitude or "fullness" (Taylor 2007) to be reachable through engagement or communion with other beings. Instead, it ultimately seeks distance from other beings, in what has been described as an "ethic of quarantine (Laidlaw 1995)". That we share our world with a myriad of life forms does not for Jains evoke rhapsodic wonderment, nor would it ever be experienced as a form of "cosmic liturgy" (Berry 2006). Instead, it is more likely experienced as a perilous and potentially suffocating reality. Indeed, for a tradition that emphasizes the need for detachment, being with others can be a treacherous affair. But Jainism also recognizes that being with others is the necessary condition for greatness. It is the very context of being with other life forms in the meaningful cosmos (lokäpuruşa) that necessitates mindfulness and gives rise to compassion, without which, enlightenment can never be achieved.

\section{The meaningfulness of Lokāpuruşa}

Jainism is renowned for its ascetic ideal and for its cultivation of a radical detachment from body and worldly pleasures in its pursuit of liberation. Because it identifies the soul's entanglement in matter as the most fundamental existential problem (one shared by all beings), the religious path is conceived of as a heroic and rigorous process of disentanglement from all forms of matter, understood to be the source of bondage, pursued in the absence of any benevolent grace-bestowing "overseer" or God. Though guidance and inspiration are sought from others, most especially from the example of the Jinas, the religious path is ultimately conceived of as a necessarily solitary one. While Jinas (or Tìrthankaras) - those human beings who have attained liberation and 
transmitted the true dharma for all to benefit from- are the recipients of worship, they exist only as exemplars of the ideal life and are neither involved with nor concerned about our worldly lives in any way. As Lawrence Babb writes in Absent Lord: "From the standpoint of transactional logic, the Tïrthankara is absent. He responds to no prayers or petitions, and dispenses no saving grace" (Babb 1996: 92). Because of this, the existence of Jainism's devotional structures that center on the Jinas is often met (at least by students of the tradition) with puzzlement. Babb gives expression to this in the opening sentence of his book when he asks: "What does it mean to worship beings that one believes are completely indifferent to, and entirely beyond the reach, of any form of worship whatsoever"? (Babb 1996:1).

Jain devotional practices have been viewed as inevitable accretions of the wider Hindu tradition. They have also, in Durkheimian fashion, been explained in terms of their powerful social functions for collective cohesion. In addition, they have been treated as rationalized activities that foster detachment, focus the mind, and remind Jains of their own divine potential. For instance, Babb describes how during püjāa, offerings are understood not as gifts given to the Jinas, but as gifts given up in emulation of them (Babb 1988), serving as pedagogical models for ideal practice.

While these explanations each contribute to our understanding of Jain ritual and devotional culture, I argue here that Jain devotional practices emerge out of something more basic: namely, their impetus arises from the pre-reflective experience of inhabiting an embodied, sensorial relationship to the world. That this world for Jains is neither a concrete manifestation of the divine, nor the purposeful creation of a "higher being", does not diminish its potential for an existential response of gratitude or devotion. The world summons a response; our existence is a predicament in need of resolution, and the Jinas are those beings who show us the way. Though Jinas no longer participate in reciprocal exchange with devotees, they encapsulate the latter's aspirations, and the goals of the Jain dharma itself. The trajectory of each Jina extends back through their many previous lives, providing devotees a longitudinal perspective on the nature of embodied existence. The Jinas enjoyed great boons and suffered profound despair, just as we all do and therefore to which we can relate. But more significantly, their lives reveal a powerful thread of narrative coherence, without which the ups and downs of existence might seem meaningless and chaotic. The Jinas therefore are beacons of calm and hope in the midst of turbulence and hardship; they embody the triumph of the path of nonviolence.

Jain devotion, therefore, can be characterized as an embodied response to the experience of a meaningful, autonomous, transpersonal lokapuruṣa (or cosmos). Despite its non-theistic "do it yourself" path, expressions of devotion and prayer naturally arise from the felt sense that one is being called to participate in a world that, though full of obstacles and potentially treacherous, invites participation.

The labyrinthine path through the quagmire of worldly existence-not unlike an intricate game of snakes \& ladders-is a world charged with importance and urgency; our participation in it, while difficult, is also the grounds for our heroism. Worldly existence-condemned for being a place of bondage-is simultaneously treated by Jains as providing the precious means for release. Indeed the very structure and workings of the cosmos serve this function, providing souls the means to move ever upward toward eventual release. For instance, the Tattvārtha Sütra (Umāsvāti 1994): 4.13-4.15, pp. 102-104 identifies the astrological planets as divine cosmic entities. As emitters of light 
and movers in predictable motion, they stand as beacons of consciousness and hence tutors of dharma. In an unpublished paper on Jain astrology, delivered at the DANAM meetings in 2008, Stephen Quinlan elucidates the central role planets play as guides to illuminate the mokşa marg. He writes:

By casting light on things and permitting temporal observation of the changes they undergo, the planets inform experience and enable the soul's inherent rationality to express itself. By casting light upon the world and following measurable paths of predictable movement, dharma is revealed and the soul's course charted. Without the planets as beacons to the soul, karmic gloom and ignorance cannot be dissipated... [And] while the original motive for the karmic bond remains outside of knowledge, the bond itself creates, however paradoxically, the conditions under which jīva comes to know itself and, as a result, its objective to release itself from karma and to express itself in its essential, liberated state (Quinlan 2008:1;3, Nd)

The world offers opportunities that serve the function of karmic release. The abundant temptations of sensual life, cursed for their allure, nevertheless present opportunities for detachment and karmic purification. And the indelible sufferings of sentient life, lamented with anguish and tears, stimulate deep compassion and spiritual progress. In Jainism, a world pregnant with potentiality opens itself up to us; it invites our participation and provides the grounds for the purposeful life.

Jains understand their lives in terms of "a calling" or response, and the devotional structures at work are simply expressions of life lived responsively to an independent realm of meaning. In brief, Jainism's valorization of "life over truth" has meant that its myriad conceptualizations (its elaborate system of reflections on the nature of existence) do not eclipse the knowledge that is immanent in experience itself, that is, the basic felt impulse to respond devotionally to the world.

I highlight this dimension because in the contemporary period, the non-rational, non-discursive elements of human experience are marginalized, as is the notion of meaning existent outside of human consciousness. Contemporary critiques of religious experience and even of the discipline of religious studies (let alone theology) often judge and condemn the phenomena and field according to very narrow criteria. Much of the critiques of New Atheism, for instance, target what are considered absurd, nonempirical beliefs, on the assumption that rational thought might shed light on an area of dark, irrational and even dangerous ignorance that spawns religious fervor and practice. Jainism is interesting because its devotional apparatus thrives in the absence of any transactional relationship with a god. As is widely observed, Jains don't worship in order to please gods, nor with the hope of getting something from gods in return. For the critics of religion, removing god (or some form of transactional entity) from the equation should effectively remove the raison d'être for religiosity itself. But of course, it does not within the Jaina context: Jains do worship, and fervently so ${ }^{\text {a }}$.

\section{Conclusion}

The Jain example suggests that devotional life in no sense necessitates the ontological existence of a God who creates, destroys and cares for us. When a cognitive relationship to the world reigns, experience is objectified in reflection before being validated, 
and when no rationale is found, its validity is undermined. Because in Jainism, due to its embodied epistemology ("life over truth"), the cognitive relationship to the world does not eclipse experience, so that we see life lived in response is not so much about belief systems or other rationalizations, but is a way of inhabiting a pre-given domain of meaning.

In conclusion, I have argued in this paper that the primary impetus for Jainism's celebrated focus on nonviolence, as well as its support of a vital devotional life, is neither ideological nor epistemological. Instead, it is relational, insofar as it inheres in the far more fundamental experience of being sentiently with others. This paper argues that embodied perceptions of a meaningful animate cosmos constitute the generative ground from which Jain epistemology (as well as philosophical and ethical reflections) emerges.

\section{Endnote}

aparaphrased from the online BBC site (http://www.bbc.co.uk/religion/religions/jainism/ worship/worship_1.shtml, 2013) on Jainism.

Competing interest

The author declares that she has no competing interests.

Received: 14 October 2013 Accepted: 14 October 2013

Published: 14 November 2013

References

Babb, L. 1988. "Giving and giving Up: the eightfold worship among Svetambar Murtipujak Jains. J Anthropol Res 44(No. 1). Spring. Pp 67-86.

BBC online site. "Jain Worship". http://www.bbc.co.uk/religion/religions/jainism/worship/worship_1.shtml.

Babb, L. 1996. Absent lord: ascetics and kings in a Jain ritual culture. Berkeley: University of California Press.

Berry, T. 2006. A communion of subjects: animals in religion, 8. Columbia University Press: New York, Chichester, West Sussex

Eliade, M. 1987. The sacred and the profane: the nature of religion. Trans. Williard tank, 107-109. San Diego: A Harvest Book, Harcourt Inc.

Laidlaw, J. 1995. Riches and renunciation: religion, economy and society among the Jains, 153. Oxford: Clarendon.

Quinlan, S. 2008. Self-definition and astral representation: astrology as a means of karmic management among Jain householders and Renouncers. Paper delivered at American academy of religion meeting.

Taylor, C. 2007. A Secular Age Harvard University Press, 2007 speaks of "fullness" in terms of an experiential mode of being, akin to plenitude or attunement, which human beings orient ourselves toward. Harvard University Press: Cambridge, Massachusetts and London England.

Umāsvāti, 1994. Trans.Nathmal Tatia. Tattvārtha Sūtra, ("That Which Is"). New York: Harper Collins Publishers.

Vallely, in Dalal, Neil (ed.), 2014. Asian Perspectives on Animal Ethics. Routledge. forthcoming.

doi:10.1186/2196-8802-1-3

Cite this article as: Vallely: Theories of knowledge and the experience of being: Jainism's ontology of kinship.

International Journal of Dharma Studies 2013 1:3.

\section{Submit your manuscript to a SpringerOpen ${ }^{\circ}$ journal and benefit from:}

- Convenient online submission

- Rigorous peer review

- Immediate publication on acceptance

- Open access: articles freely available online

- High visibility within the field

- Retaining the copyright to your article

Submit your next manuscript at $>$ springeropen.com 